\title{
Experimental Investigation of Lime Mortar Used in Historical Buildings in Becin, Turkey
}

\author{
Adem SOLAK* \\ Pamukkale University, Faculty of Architecture and Design, Department of Architecture, 20070, Kinıklı/Denizli, Turkey \\ cross ${ }^{\text {ref }}$ http://dx.doi.org/10.5755/j01.ms.22.1.9022
}

Received 31 December 2014; accepted 09 April 2015

\begin{abstract}
It is of great importance that the architectural and engineering disciplines work together in the restoration studies of historical buildings which are our cultural heritages. It is required that the bearing system and the materials of the structures should be investigated in detail prior to any conservation. The determination of the properties and compositions of the mortar material used in the construction of the historical building is one of the most important phases of the conservation studies and it is the main purpose of this study. In the scope of the study, the basic physical and mechanical properties, micro structures, raw material compositions, mineralogical and chemical properties of historical mortars taken from Kizil Khan, Karapasah Madrasah and Yelli Mosque structures in Becin antique city are determined. As a result of the study, it is determined that all mortar samples have hydraulic properties that is a result of hydraulic properties of binder lime.

Keywords: historical buildings, mortar composition, micro structural investigation, structural materials.
\end{abstract}

\section{INTRODUCTION}

Historical buildings named as indicator of cultural heritages have crucial functions that establish a bond with antecedents and they should be carefully carried into future. Due to the fact that Turkey is located in active seismic region, the seismic risk analysis of historical buildings and therefore examination of the mechanical properties for the materials used in such buildings become compulsory before their restorations. It was emphasized to use orginal materials in retrofitting of historical buildings in Venedic Specifications published in 1964 and adopted by our country [1]. The accurate defining of orginal materials plays a basic step in shedding light on restoration investigations that will be made in the future [2-6].

In the past, lime mortars were commonly used as a structural bond material in historical buildings since The Roman Empire [7-9]. Lime mortar is one of the binding materials that hold together the material of historical structures like stones and bricks and it is obtained by mixing lime and aggregates. Lime mortars can be classified into two groups according to presence of hydraulic compounds as hydraulic and non hydraulic [10]. Non-hydraulic mortars are obtained from the mixture of pure lime and pozzolanic aggregates. Non-hydraulic lime mortar gains its strength as a result of the conversion of lime to carbonate $\left(\mathrm{CaCO}_{3}\right)$ via calcium carbon dioxide of the air [11]. Hydraulic lime mortars are obtained by using hydraulic lime or pure lime by mixing pozzolanic aggregates. The strength of mortars prepared with hydraulic limes increases with calcium-silicate-hydrate (C-S-H) and calcium-aluminum-hydrate (C-A-H) by developing calcium silicates and aluminates reacting with water. In hydraulic mortars obtained by using pozzolanic

\footnotetext{
* Corresponding author. Tel.: +90-258-2962552; fax: +90-258-2962415

E-mail address: asolak@pau.edu.tr (A. Solak)
}

aggregates due to the reaction of pure lime with pozzolanics calcium-silicate-hydrate $(\mathrm{C}-\mathrm{S}-\mathrm{H})$ and calciumaluminum-hydrate (C-A-H) are formed. Due to the newly formed compounds, hydraulic mortars have higher mechanical properties and resistances in comparison to the non-hydraulic mortars.

In this study, the material properties of lime mortar used in historical stone structures (14 ${ }^{\text {th }}$ century) in the ancient city of Becin, located in southwest Turkey and hosted many civilizations (Byzantine, Ottoman and Menteshe Emirate), were be determined.

\section{MATERIALS AND METHODS}

The scope of this study considers eight samples of lime mortars obtained from stone structures of Kizil Khan, Karapasah Madrasah and Mosque of Yelli, which are located in the ancient city of Beçin built in $14^{\text {th }}$ century. Six of them are from joint mortar and two samples are from plaster mortar. Samples under the study are named according to building names and number of samples from that building. The macro-structures, the basic physical and mechanical properties, microstructures of mortar and plaster samples, raw material compositions and mineralogical and chemical properties were determined. Descriptions and locations of the examined samples are given in Fig. 1 - Fig. 3 and in Table 1.

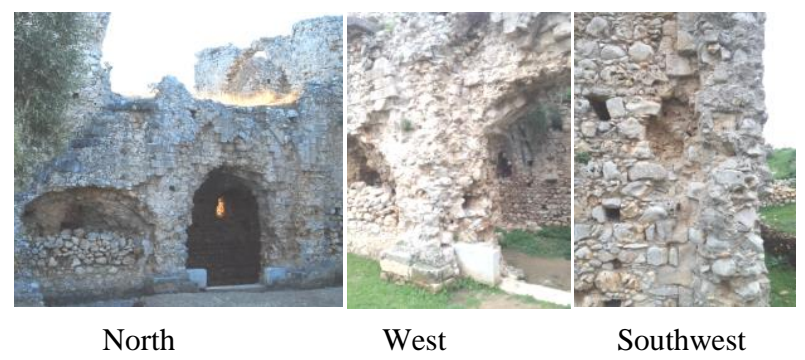

Fig. 1. Facade views of Kizil Khan 
Table 1. Description of the studied mortar samples

\begin{tabular}{|c|c|}
\hline Sample & Descriptions \\
\hline KH-1 & Joint mortar from northern facade wall - Kizil Khan \\
\hline KH-2 & Joint mortar from western facade wall - Kizil Khan \\
\hline KH-3 & Joint mortar from southwest facade wall - Kizil Khan \\
\hline KPM-1 & $\begin{array}{c}\text { Joint mortar from southeast facade wall - Karapasah } \\
\text { Madrasah }\end{array}$ \\
\hline KPM-2 & $\begin{array}{c}\text { Joint mortar from southwest facade wall - Karapasah } \\
\text { Madrasah }\end{array}$ \\
\hline KPM-3 & $\begin{array}{c}\text { Plaster mortar from west facade wall - Karapasah } \\
\text { Madras }\end{array}$ \\
\hline YC-1 & Joint mortar from east facade wall - Yelli Mosque \\
\hline YC-2 & $\begin{array}{c}\text { Interior plaster mortar from east facade wall- Yelli } \\
\text { Mosque }\end{array}$ \\
\hline
\end{tabular}

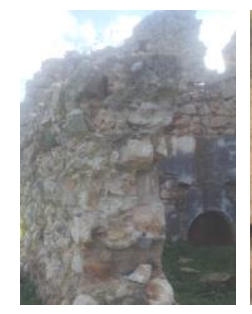

Southeast

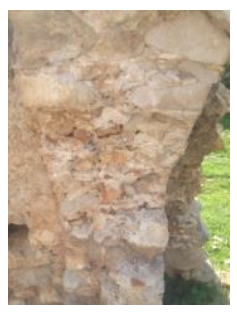

Southwest

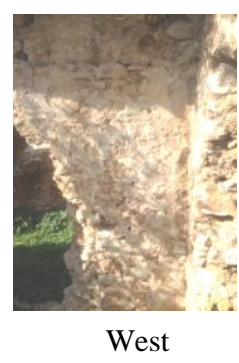

Fig. 2. Facade views of Karapasah Madrasah

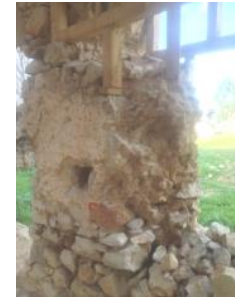

East

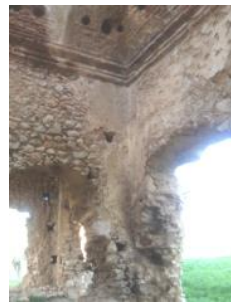

West
Fig. 3. Facade views of Yelli Mosque

The shape, size, hardness (mortar hardness have been determined according to the standart procedure defined in TS 6809, in which Mohs hardness of constituent minerals in the mortar have been obtained by comparing with minerals with known hardness [12]), color and texture of the materials were determined in macro level by using Nikon stereo microscope.

In order to determine physical properties of the mortar samples, pycnometer and water absorption experiments were carried out by standard tests generally based on the same principles and given in the literature [13-15]. Water absorption rate $(S k, S h)$ defined by mass and volume of samples, actual densities ( $\delta$ : specific mass) and porosity $(P)$ values were determined.

Uniaxial compressive strengths $(\sigma)$ of mortars were determined by mechanical testing device (Toni Technic) for those of appropriate geometry and by point loading tools (YKM-S221) for mortars with non-suitable geometry. By comparing the results obtained from these two experiments the strength conversion factor $(K)$ is calculated [16-18].

With the use of acid loss and sieve analysis, raw material compositions of the mortar were defined by the ratios of binder/aggregate (B/A) (used in mortar) and particle size distribution for the aggregate. Amounts of lime and aggregate were defined by solving calcified lime $\left(\mathrm{CaCO}_{3}\right)$ of $10 \%$ dilute in hydrochloric $(\mathrm{HCl})$ acid [19]. Grain size of aggregates have been determined after acid loss analysis by using sieves with hole sizes in the range of 75 to 9500 microns.

There are various methods available for determining the pozzolanic activity in the literature and these are classified as direct and indirect methods [20, 21]. Among the indirect methods, electrical conductivity method is preferred due to its low sample material waste and low duration. On the other hand, the method has no standart and can be used in modified form [22, 23]. The values of pozzolanic activity for the aggregates were determined by measuring changes in electrical conductivity before and after mixing saturated calcium hydroxide solution solved in acid mixed with fine-grained aggregates lower than 90 micrometers. The range of $0.4-1.2 \mathrm{mS} / \mathrm{cm}$ for the difference between electrical conductivities shows that aggregates are featured pozzolanic and the value above $1.2 \mathrm{mS} / \mathrm{cm}$ indicates that material has very pozzolanic property [24]. Electrical conductivity values are measured with HQ40d model multimeter.

Hydraulic properties of mortars were determined by thermographical analysis and ignition loss method. SHIMADZU DTG-60H model device has been used for TGA/DTA analysis. In the analysis $11 \mathrm{mg}$ powdered samples have been used. In order to remove the effect of atmospheric gases, analysis have been performed in nitrogen environment and gas flow velocity has been set to $100 \mathrm{~mL} / \mathrm{min}$. Heat flux values have been set for 10 degrees increase per minute $\left(10^{\circ} \mathrm{C} / \mathrm{min}\right)$. As a result of the analysis, percent mass loss as a function of temperature change have been determined for the temperature intervals of $0-120^{\circ} \mathrm{C}, 200-600^{\circ} \mathrm{C}$, and $600-900^{\circ} \mathrm{C}$. Loss of hygroscopic water (up to $120^{\circ} \mathrm{C}$ ), loss of structurally bond water $\left(200-600{ }^{\circ} \mathrm{C}\right)$ and the loss of $\mathrm{CO}_{2}\left(600-900{ }^{\circ} \mathrm{C}\right)$ were determined. Hydraulic properties of mortar were evaluated with the proportion of loss carbon dioxide to water percentiles and if this ratio is lower than 10 , it was adopted that mortar has hydraulic property [4-25].

Protein and fat tests were conducted to detect whether fat and protein-based organic materials were added into the content of compositions of mortar and plaster mixtures. Protein test was made by using Gerhardt Vapodest 40s device. Protein content was calculated using the total nitrogen determined by Kjeldahl method with subsequent multiplication by the factor 6.25 [26].

In the process of oil detection, powder samples are placed on a glass, mixed with added copper sulphate $\left(\mathrm{CuSO}_{4}\right)$ crystals and one or two drop of concentrated $\mathrm{NH}_{3}$ solution has been added. Then reaction is completed with the addition of hydrogen peroxide $\left(\mathrm{H}_{2} \mathrm{O}_{2}\right)$. Permanent soap bubbles after 20 minute is an indication of oil existence. If the bubbles are temporary, there is no oil [27].

Microstructural properties of lime and aggregates used in mortars have been determined with Scanning Electron Microscope with EDS unit.

Mineralogical features of the lime used in the aggregates were determined by using petrographic analysis through polarized microscope (Leica DM750P), and also by using X-Ray Diffraction (XRD) instrument (Rigaku Mini Flex) known as advanced analysis techniques. 
Chemical compositions of the mortars were determined by means of the apparatus of the X-ray fluorescence spectrometry (Spectro PEDXRF XEPOS-II).

\section{RESULTS AND DISCUSSION}

\subsection{Macro structural analysis of mortar with the physical, mechanical properties and compositions of raw materials}

All mortar samples have been observed in a porous structure and their colors vary from yellowish beige-white up to dark gray-black in different colors. It has been observed that the mortars were composed of partially rounded mineral and rock components in different particle sizes (from silt size up to $1 \mathrm{~cm}$ ) and binding material surrounding the particles as shown by Benedetti et al. [28]. The hardness of the mortars was between 4.5-6 Mohs.

Physical properties of mortar samples are given in Table 2 and summarized as follows actual densities ( $\delta$ : specific mass) of the samples were found to be $2.67-2.80 \mathrm{~g} / \mathrm{cm}^{3}$, the percentage by mass of water absorption $(S k)$ was $9.9-14.3 \%$, the percentage by volume of water absorption $(S h)$ was $18.6-25.6 \%$ and the porosity values were $30-38 \%$. Density and porosity values obtained from the current study are in good agreement with the literature based on the same type of hydraulic mortars obtained by using hydraulic limes. For example, in the work of Stefanidou hydraulic mortars porosity values are very close to the present study [29]. Also present results show good agreement with the results of Oguz et al. on Seljukian harbor in Antalya, in which they found $30 \%$ porosity and $2.63 \mathrm{~g} / \mathrm{cm}^{3}$ density values [30]. In other Seljucian structure Ulukaya et al. determined a density value of $2.7 \mathrm{~g} / \mathrm{cm}^{3}$ and in Bizantian structure the same authors obtained a density value of $2.63 \mathrm{~g} / \mathrm{cm}^{3}$. In their study the porosity was $35.4 \%$ [31]. In a recent study by Kozlu for Kizılkosk, which is a Seljucian building, density was $2.62 \mathrm{~g} / \mathrm{cm}^{3}$ and for the Gupgupoglu Bath from Ottoman time density was $2.77 \mathrm{~g} / \mathrm{cm}^{3}$ [27]. In additon to density and porosity values, the percentage by mass of water absorption and the percentage by volume of water absorption which are given in Table 2 are also in good agreement with the findings of Kozlu and Oguz et al $[27,30]$.

Table 2. Test results for loss in acid, binder/aggregate ratio (B/A), physical and mechanical properties of mortar

\begin{tabular}{|c|c|c|c|c|c|c|c|}
\hline Sample & $\begin{array}{c}\text { Acid } \\
\text { loss } \\
\text { ratio } \\
\%\end{array}$ & $\begin{array}{c}\mathrm{B} / \mathrm{A} \\
\text { ratio }\end{array}$ & $S k, \%$ & $S h, \%$ & $\delta, \mathrm{g} / \mathrm{cm}^{3}$ & $P, \%$ & $\sigma, \mathrm{MPa}$ \\
\hline $\mathrm{KH}-1$ & 33.1 & $1 / 2$ & 9.9 & 18.6 & 2.67 & 30 & 1.41 \\
\hline $\mathrm{KH}-2$ & 50.1 & $1 / 1$ & 13.6 & 23.9 & 2.72 & 35 & 1.14 \\
\hline $\mathrm{KH}-3$ & 32.1 & $1 / 2$ & 13.5 & 23.8 & 2.74 & 38 & 2.45 \\
\hline KPM-1 & 48.7 & $1 / 1$ & 10.8 & 20.7 & 2.71 & 30 & 1.83 \\
\hline KPM-2 & 49.3 & $1 / 1$ & 10.9 & 20.8 & 2.70 & 29 & 1.92 \\
\hline KPM-3 & 56.1 & $1 / 1$ & 10.5 & 19.0 & 2.71 & 33 & 3.86 \\
\hline YC-1 & 33.5 & $1 / 2$ & 14.2 & 25.6 & 2.78 & 36 & 1.00 \\
\hline YC-2 & 53.5 & $1 / 1$ & 14.3 & 25.8 & 2.80 & 35 & 1.01 \\
\hline
\end{tabular}

The uniaxial compressive strengths of $\mathrm{KH}-3$ and KPM-3 samples with suitable geometry were found by using a mechanical test device, and point-load device was used for samples with non-suitable geometry. The results obtained prom these two tests were compared and strength conversion factor $(K)$ was found to be 10 . The compressive strengths $(\sigma)$ of all samples obtained by using this value are presented in (Table 2). Average uniaxial compressive strength of the samples from Kizil Khan, Karapasah Madrasah and Yelli Mosque structures are 1.67 MPa, $2.54 \mathrm{MPa}$, and $1.0 \mathrm{MPa}$ respectively. In the study of Ulukaya et al. average uniaxial compressive strength of the samples from Bizantian structure were in the range of $1.0-2.2 \mathrm{MPa}$ and in Seljucian stracture it was between 1.6 $\mathrm{MPa}$ and 2.9 $\mathrm{MPa}[31]$.

The ratio of the binder/aggregate (B/A) of mortar samples varied between $1 / 2$ and $1 / 1$ (Table 2). Binder/aggregate ratios were the subject of many studies. Ugurlu et al. investigated this ratio for Roman time structures (Aigai and Nysa) and they found that the ratio was in between $1 / 4$ and 1/1 [32]. In another study by Kozlu on Kizilkosk and Gupgupoglu Bath, the mentioned ratio was in between 1/2-1/1 [27]. The results of the above mentioned two studies are in good agreement with the present study.

The results of sieving analysis of the mortar samples for the determination of grain size distribution are given in Fig. 4. In all samples maximum aggregate grain size was determined to be $8 \mathrm{~mm}$. Grain size aggregates of more than $1 \mathrm{~mm}$ were observed up to $30-50 \%$ of the total aggregate. Findings of Benedetti et all. on Roman time and Oguz et al. on Seljucian structures are similar with the present findings $[28,30]$.

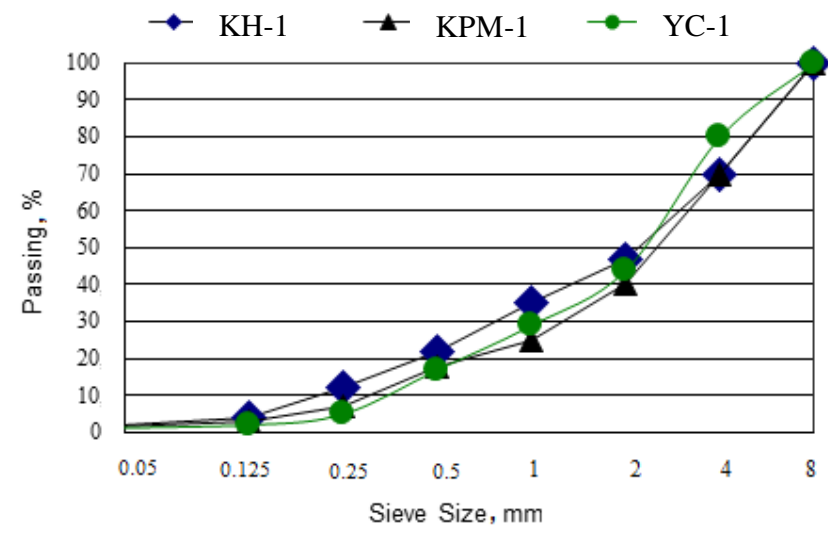

Fig. 4. Results of sieving analysis of the mortar samples 'KH-1, KPM-1, YC-1'

Test results Pozzolanic activity, protein and fat analysis are shown in Table 3 .

Table 3. Results of pozzolanic activity, protein and fat

\begin{tabular}{|c|c|c|c|}
\hline Sample & $\begin{array}{c}\text { Pozzolanic } \\
\text { activity, mS/cm }\end{array}$ & Protein, $\%$ & Fat, \% \\
\hline KH-1 & 0.6 & 0.65 & - \\
\hline KH-2 & 0.7 & 0.60 & - \\
\hline KH-3 & 0.5 & 0.55 & - \\
\hline KPM-1 & 0,6 & 0.99 & - \\
\hline KPM-2 & 0.7 & 0.95 & - \\
\hline KPM-3 & 0.6 & 1.00 & - \\
\hline YC-1 & 0.4 & 0.41 & - \\
\hline YC-2 & 0.5 & 0.43 & - \\
\hline
\end{tabular}

Table 3 shows that for the samples pozzolonic activity values are in between 0.4 and 0.7 . They all are much lower 
than 1.2 value, which is a lower limit for very good pozzolonics. According to these results, all samples are normal pozzolonics.

From protein and fat analysis of the mortars, traces of fat in the samples were not found but maximum amount of protein in the mortars was about $1 \%$ (Table 3 ).

\subsection{Microstructural analyses of mortars (SEM/EDS analysis)}

Microstructural properties of lime used in mortars have been determined by examining carbonated lime in mortar matrix via SEM analysis coupled to EDS unit.

Based on SEM, the grain sizes of calcite and other crystals which form lime are determined to be smaller than 4 microns. In addition, grain sizes are almost uniform and homogeneously distributed (Fig. 5 a, b).
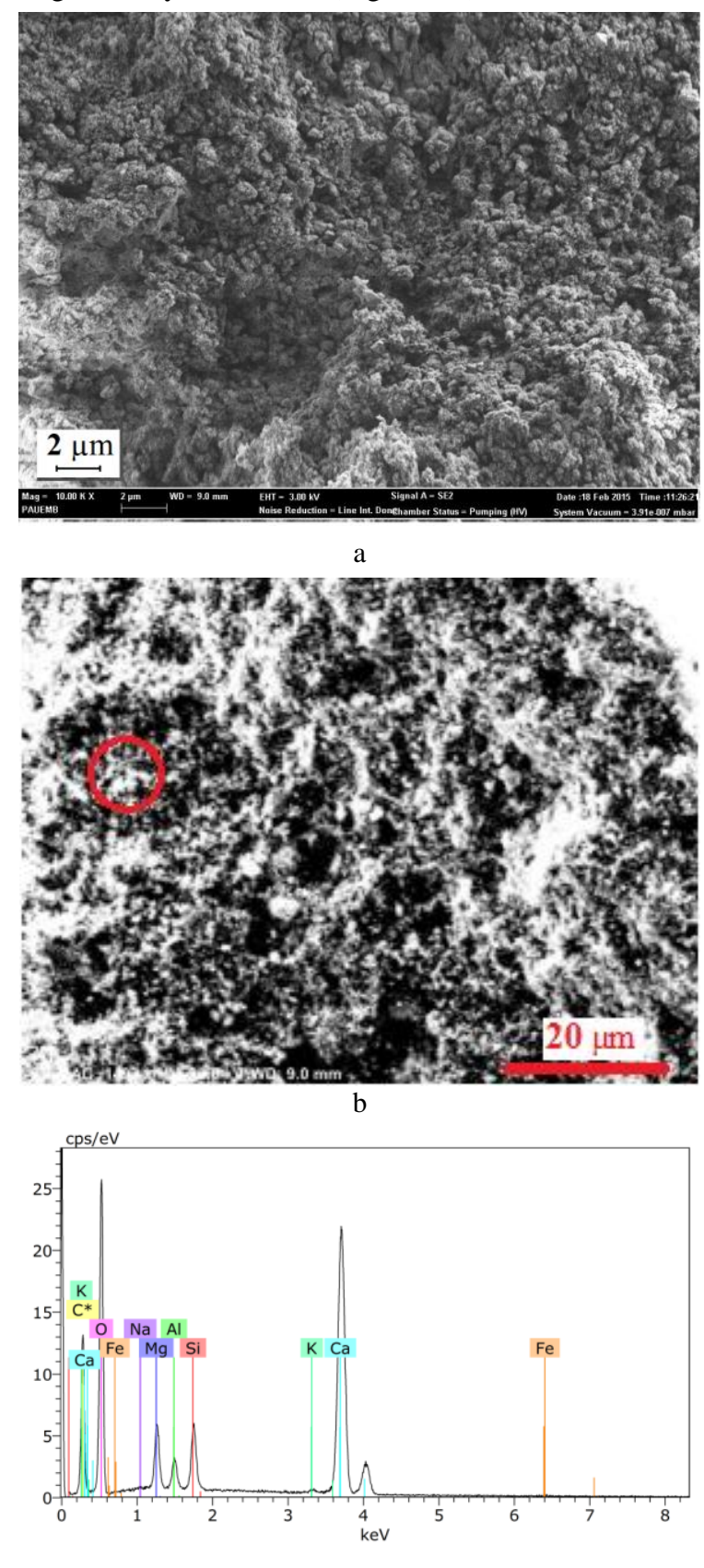

$c$

Fig. 5. KPM1 lime SEM/EDS images with magnitude: $a-10.000 x$ for SEM; $b-1.500 x$ for SEM; $c$-EDS image
EDS analysis also revealed that the $\mathrm{Ca}$ has the highest percentage and $\mathrm{Mg}, \mathrm{Si}, \mathrm{Al}, \mathrm{K}$ and $\mathrm{Fe}$ are present in the lime (Fig. 5 c). The chemical coefficient calculated by the ratio of molecular weight of $\mathrm{CaO}$ to atomic weight of $\mathrm{Ca}$ was used to convert elemental values such as $\mathrm{Ca}, \mathrm{Si}$, etc. from the carbonated lime to oxides ones $\left(\mathrm{CaO}, \mathrm{SiO}_{2}\right.$, etc. $)$ as indicated in Table 4.

In SEM/EDS analysis of aggregates high amount of $\mathrm{SiO}_{2}$ and $\mathrm{Al}_{2} \mathrm{O}_{3}$ have been detected. Analysis also reveals that aggregates in the binder of mortars are properly binded with lime.

Table 4. KPM-1 Lime EDS Analysis Results

\begin{tabular}{|c|c|c|c|}
\hline Element & $\%$ & Oxide & $\%$ \\
\hline $\mathrm{O}$ & 62.06 & - & - \\
\hline $\mathrm{Ca}$ & 19.21 & $\mathrm{CaO}$ & 26.87 \\
\hline $\mathrm{Mg}$ & 3.55 & $\mathrm{MgO}$ & 5.89 \\
\hline $\mathrm{Al}$ & 1.50 & $\mathrm{Al}_{2} \mathrm{O}_{3}$ & 2.83 \\
\hline $\mathrm{Si}$ & 4.29 & $\mathrm{SiO}_{2}$ & 9.17 \\
\hline $\mathrm{Fe}$ & 0.07 & $\mathrm{Fe}_{2} \mathrm{O}_{3}$ & 0.09 \\
\hline $\mathrm{K}$ & 0.17 & $\mathrm{~K}_{2} \mathrm{O}$ & 1.05 \\
\hline $\mathrm{Na}$ & 0.55 & $\mathrm{Na}_{2} \mathrm{O}$ & 0.74 \\
\hline $\mathrm{C}$ & 8.60 & - & - \\
\hline
\end{tabular}

In order to determine hydraulic characteristics of lime, chemical compositions of the lime have been calculated by using hydraulicity and cementation index [33,34]. Hydraulicity (H.E) and cementation index (CE) formulas are given below as Eq. 1 and Eq. 2:

$$
\begin{aligned}
& \mathrm{H} . \mathrm{E}=\left(\% \mathrm{Al}_{2} \mathrm{O}_{3}+\% \mathrm{Fe}_{2} \mathrm{O}_{3}+\% \mathrm{SiO}_{2}\right) /(\% \mathrm{CaO}+\% \mathrm{MgO}) \\
& \text { C.E }=\left(2.8 \% \mathrm{SiO}_{2}+1.1 \% \mathrm{Al}_{2} \mathrm{O}_{3}+0.7 \% \mathrm{Fe}_{2} \mathrm{O}_{3}\right) /(\% \mathrm{CaO}+ \\
& +1.4 \% \mathrm{MgO})
\end{aligned}
$$

Limes with hydraulicity values lower than 0.1 and cementation index lower than 0.3 are classified as nonhydraulic limes [34]. Hydraulicity and cementation index of the examined lime samples are in between 0.37 and 0.50 , 0.70 and 0.90 respectively. These results show that hydraulic limes are used for making mortars.

\subsection{Mineralogical properties of mortar}

\subsubsection{Results of petrographic analysis}

In the petrographic analysis of the Kizil Khan mortar specimens, grain sizes were observed as squared, quartzite partially rounded, mica, feldspar and rarely sandstone grains (Fig. 6 a, b, c) and limestone particles were also observed. In all specimens, the matrix material is fine grain lime. Some pores were observed in the matrix (Fig. 6 b, c).

In the petrographic analysis of Yelli mosque specimens, various grain sizes from thin up to large quartzite, mica, feldspar minerals, as well as round micritic limestone particles have been observed. Furthermore, the particles of rocks were determined to have volcanic and metamorphic origins (Fig. 7).

In the petrographic analysis of Karapasah Madrasah mortar specimens, different sizes and shapes of quartz, quartzite, schist, rarely limestone components (Fig. 8 a) were observed in addition to quite large size piece of rounded basalt syphilitic (Fig. 8 b). It has been determined that lime binder is rather fine-grained and it has plenty of void (Fig. $8 \mathrm{c}$ ). 

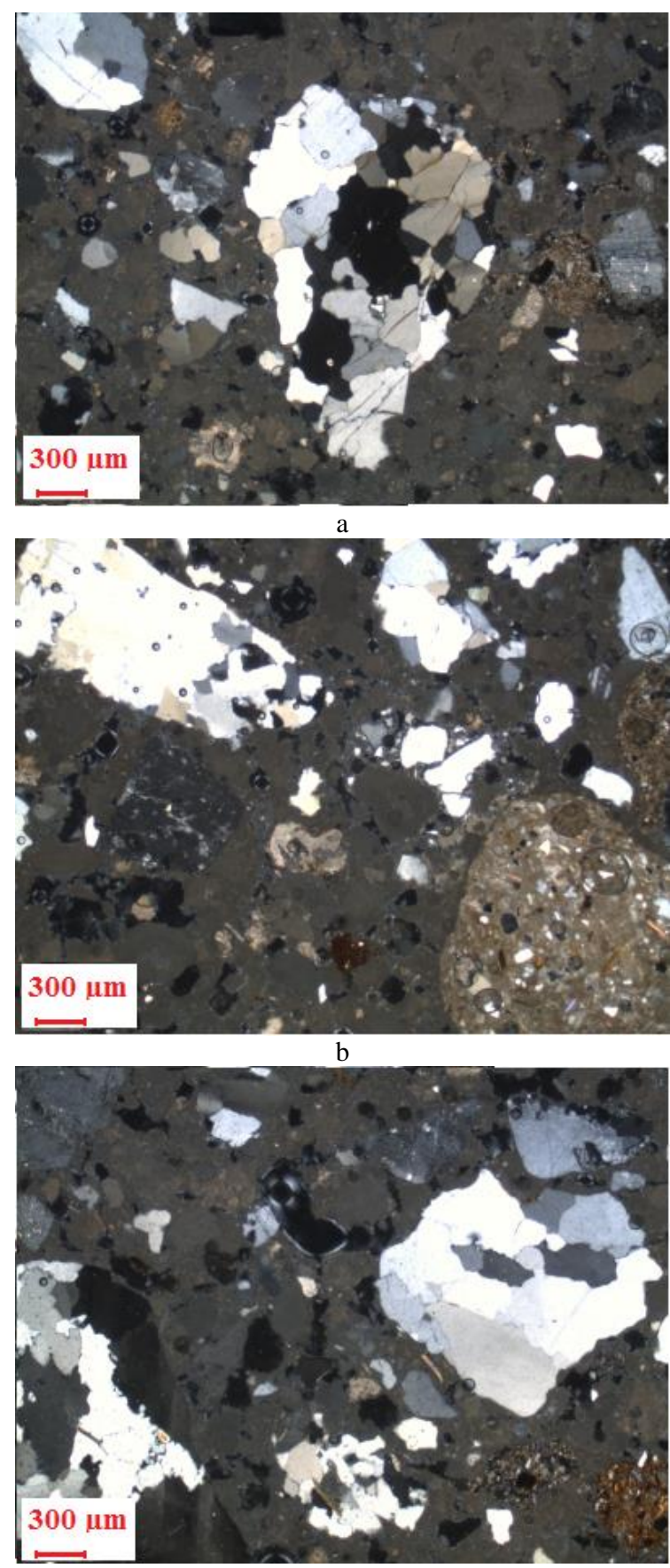

Fig. 6. Polarized microscope views of Kizil Khan mortar: $\mathrm{a}$-general texture; $\mathrm{b}$ - binder matrix; $\mathrm{c}$-sandstone

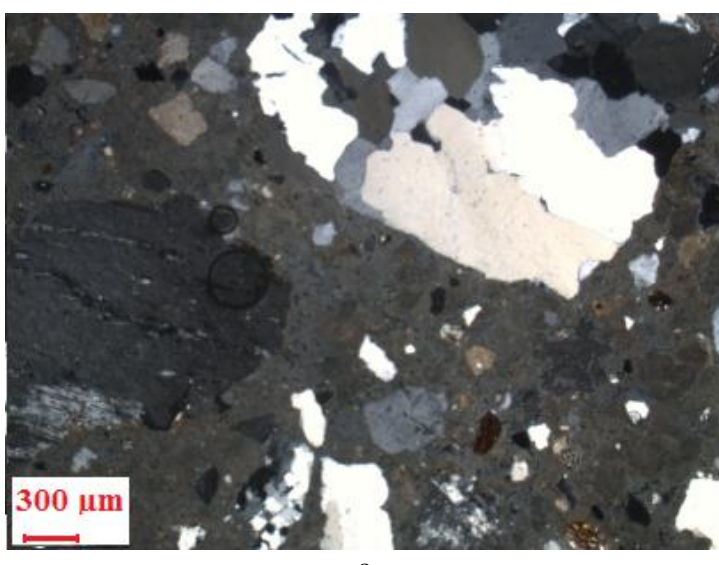

a

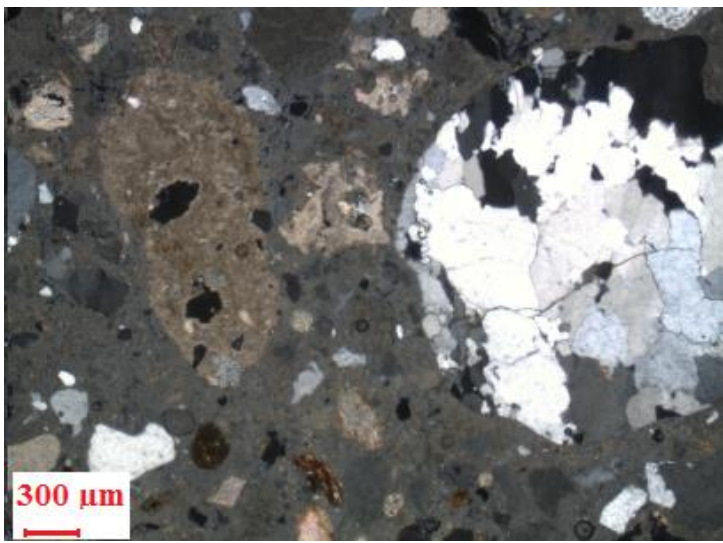

Fig. 7. Polarized microscope views of Yelli Mosque: $\mathrm{a}, \mathrm{b}$ - general texture

\subsubsection{XRD (X-Ray Diffraction) analysis}

Quartz, Calcite and feldspar minerals were found in the KH-1 and YC-1 samples examined by XRD analysis. Weak peaks of clay minerals and dolomite minerals (only $\mathrm{KH}-2$ ) have been observed in KH-2, KH-3, KPM-1 and KPM-3 but no calcium silicate hydrate (CSH) was found (Fig. 9 and Table 5). Calcite and dolomite peaks were derived from lime. Quartz and Feldspar (albite) represent the aggregates in the mortar. Additionally, it was found by $\mathrm{XRD}$ analysis that the feldspar mineral is the albite mineral, which is a $\mathrm{NaAlSi}_{3} \mathrm{O}_{8}$ component. Milas district was composed of albite stratums [35] and confirmed the finding of albite mineral in the samples analyzed by XRD tests. Mineralogical structure obtained from the analysis are similar to related literature findings [31, 32].

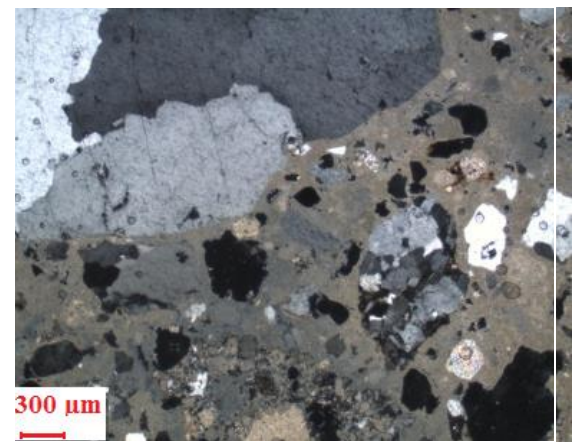

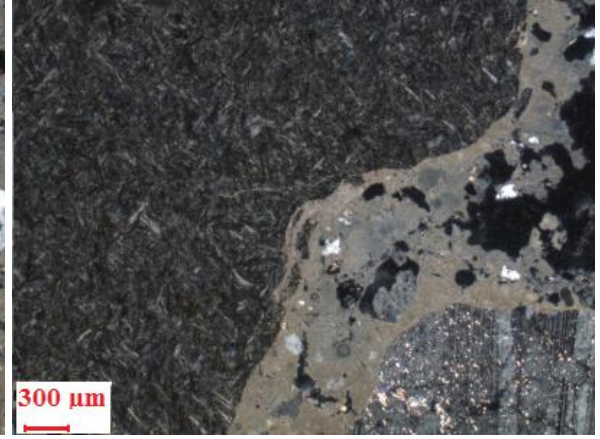

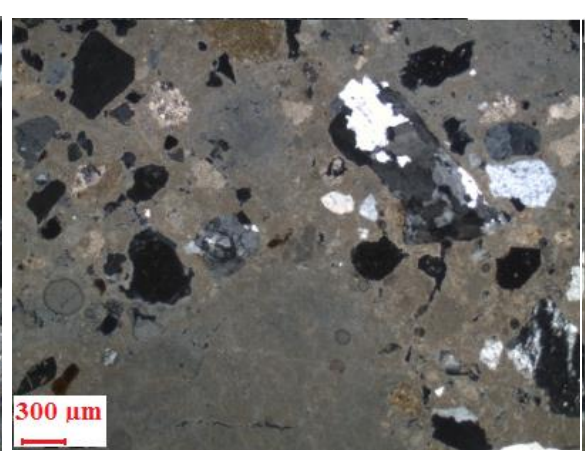

$\mathrm{c}$

Fig. 8. Microscope views of Karapasah Madrasah material: a - general texture; $b$-spillitic bazalt; $c$-binder matrix 
For instance, Ulukaya et al. [31] were not able to detect C-S-H and Ugurlu and Boke [32] determined Quartz, Albite and Muskovite dominant minerals in aggregates of Roman structure by using XRD method.
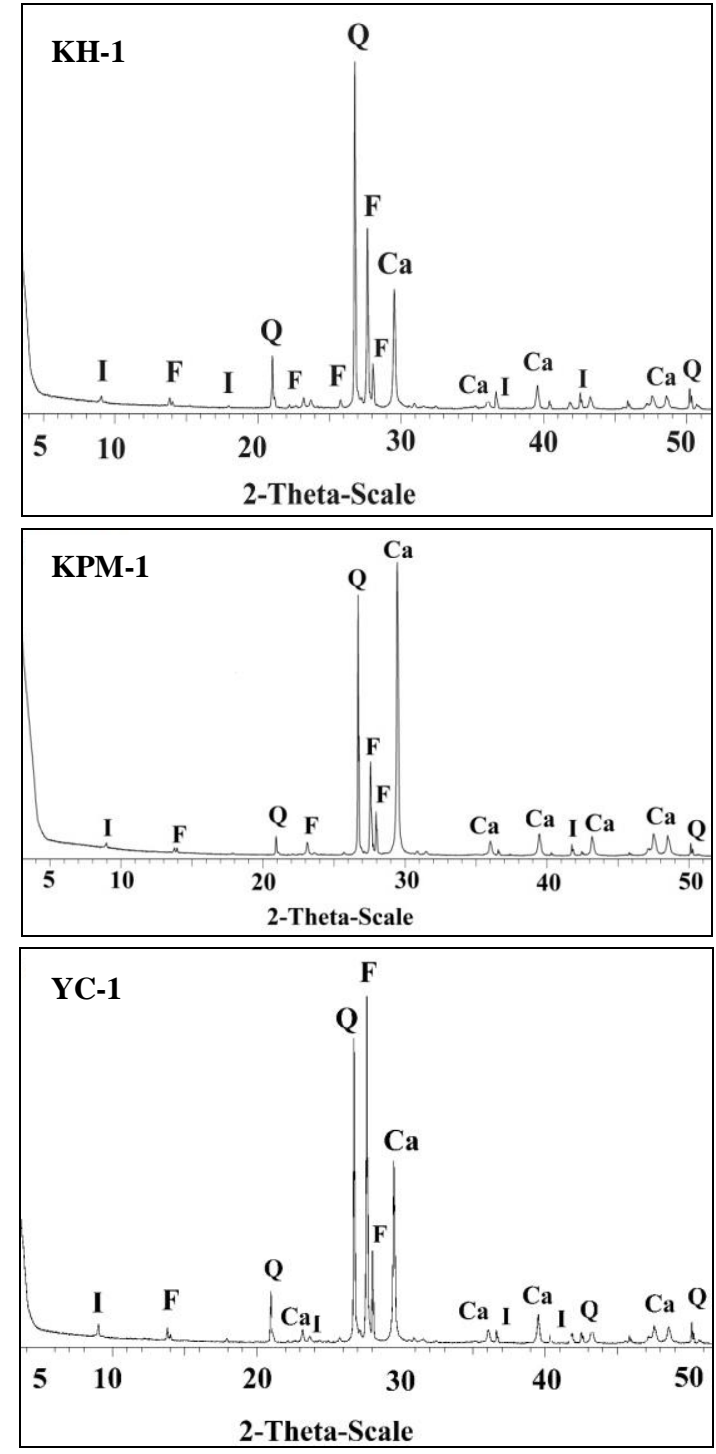

Fig 9. XRD Patterns of Studied Samples KH-1, KPM-1, YC-1 (Q:Quartz, Ca:Calcite, F:Feldspar, I:Illite)

Table 5. Results of XRD tests

\begin{tabular}{|c|c|c|}
\hline Sample & Major phase, \% & Minor phase, \% \\
\hline \multirow{2}{*}{ KH-1 } & $\begin{array}{c}\text { Calcite(34) Feldspar(31) } \\
\text { Quartz(25) }\end{array}$ & Illitic clay (10) \\
\hline \multirow{2}{*}{ KH-2 } & Calcite (42) & Feldspar(9) \\
& Quartz(42) & $\begin{array}{c}\text { Illitic clay(4) } \\
\text { Dolomite(3) }\end{array}$ \\
\hline \multirow{2}{*}{ KH-3 } & Quartz (43) & Illitic clay(10) \\
& Calcite (37) & Feldspar (10) \\
\hline \multirow{2}{*}{ KPM-1 } & Calcite (47) & Illitic clay (8) \\
& Quartz (36) & Feldspar (9) \\
\multirow{2}{*}{ KPM-3 } & Quartz (57) & Illitic clay(4) \\
& Calcite (31) & Feldspar (8) \\
\hline \multirow{2}{*}{ YC-1 } & Calcite(42) & Illitic clay (10) \\
\hline
\end{tabular}

\subsection{Chemical compositions of mortars-XRF results}

Chemical characteristics of the mortars were defined by determining oxide components of substances in mortars via XRF method. Since mineralogical evaluation of the mortar may not provide accurate results, the evaluation of powder samples prepared for XRF analysis would be necessary in conjunction with other methods such as SEM/EDS analysis (Table 6). According to the results of XRF test samples contain high proportions of $\mathrm{CaO}$ (\% 29-49), $\mathrm{SiO}_{2}$ (\% 17-44), $\mathrm{Al}_{2} \mathrm{O}_{3}(\%$ 3-6) and lower proportions of $\mathrm{Na}_{2} \mathrm{O} \quad(\% 0.4-0.8), \quad \mathrm{Fe}_{2} \mathrm{O}_{3} \quad$ (\% 0.7-1.9), $\mathrm{MgO}(\% 0.7-0.9), \mathrm{K}_{2} \mathrm{O}$ (\% 1.2-3.2).

Similar to XRF analysis given in Table 6, SEM/EDS analysis of mortars shows that $\mathrm{CaO}, \mathrm{SiO}_{2}$ and $\mathrm{Al}_{2} \mathrm{O}_{3}$ minerals are dominant, besides small amount of silicates are found.

Table 6. Results of XRF tests

\begin{tabular}{|c|c|c|c|c|c|c|c|}
\hline Sample & $\begin{array}{c}\mathrm{SiO}_{2}, \\
\%\end{array}$ & $\begin{array}{c}\mathrm{Al}_{2} \mathrm{O}_{3}, \\
\%\end{array}$ & $\begin{array}{c}\mathrm{Fe}_{2} \mathrm{O}_{3}, \\
\%\end{array}$ & $\begin{array}{c}\mathrm{MgO}, \\
\%\end{array}$ & $\begin{array}{c}\mathrm{CaO}, \\
\%\end{array}$ & $\begin{array}{c}\mathrm{Na}_{2} \mathrm{O}, \\
\%\end{array}$ & $\begin{array}{c}\mathrm{K}_{2} \mathrm{O}, \\
\%\end{array}$ \\
\hline $\mathrm{KH}-1$ & 44.6 & 5.4 & 1.8 & 0.7 & 29.1 & 0.8 & 3.1 \\
\hline $\mathrm{KH}-2$ & 17.6 & 2.6 & 0.7 & 0.7 & 49.8 & 0.4 & 1.3 \\
\hline $\mathrm{KH}-3$ & 38.0 & 5.2 & 0.6 & 0.7 & 35.2 & 0.7 & 2.8 \\
\hline $\mathrm{KPM}-1$ & 16.8 & 2.5 & 0.9 & 0.8 & 49.6 & 0.3 & 1.2 \\
\hline KPM-3 & 24.5 & 3.8 & 0.6 & 0.6 & 44.5 & 0.4 & 1.9 \\
\hline YC-1 & 32.1 & 5.1 & 1.4 & 0.9 & 39.5 & 0.7 & 2.9 \\
\hline
\end{tabular}

\subsection{Hydraulic properties of mortars}

Percent mass loss of mortars as a function of temperature change at certain temperature intervals have been determined by using TGA/DTA analysis. Samples have been heated up to $1050{ }^{\circ} \mathrm{C}$ and endothermic reactions have been evaluated (Fig. 10). Average $\mathrm{CO}_{2} / \mathrm{H}_{2} \mathrm{O}$ ratios of the mortar samples from Kizılhan, Karapasa and Yelli Mosque are 4.58, 6.12, 5.08 respectively (Table 7).

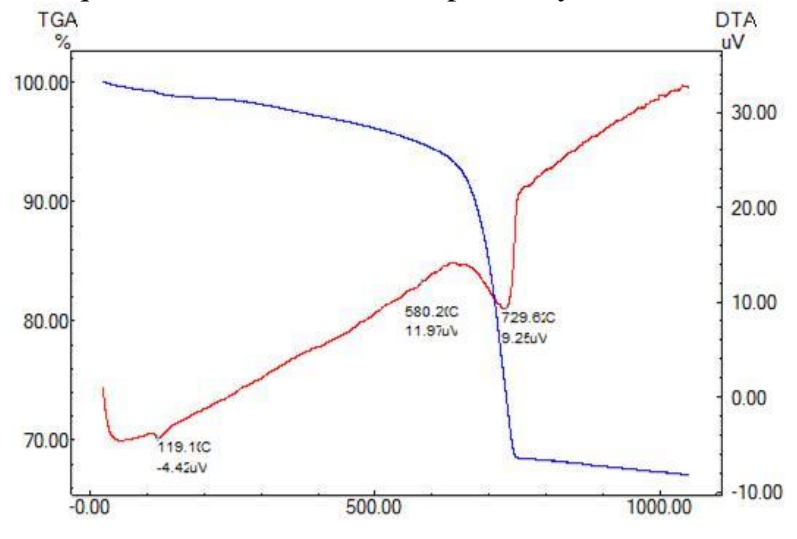

Temperature, ${ }^{\circ} \mathrm{C}$

Fig. 10. KPM-1 mortar sample TGA/DTA graph

Table 7. Results of hydraulic properties of mortars

\begin{tabular}{|c|c|c|c|c|}
\hline \multirow[b]{2}{*}{ Sample } & \multicolumn{4}{|c|}{ TGA/DTA } \\
\hline & $\begin{array}{c}\text { Loss of } \\
\text { hygroscopic } \\
\text { water, \% }\end{array}$ & $\begin{array}{c}\text { Loss of } \\
\text { structurally } \\
\text { bond water } \\
\mathrm{H}_{2} \mathrm{O}, \%\end{array}$ & $\begin{array}{c}\text { Loss of } \\
\mathrm{CO}_{2}, \\
\%\end{array}$ & $\begin{array}{c}\text { Hydraulic } \\
\text { property } \\
\mathrm{CO}_{2} / \mathrm{H}_{2} \mathrm{O}\end{array}$ \\
\hline KH-1 & 0.70 & 4.19 & 18.90 & 4.51 \\
\hline KH-2 & 0.80 & 4.30 & 20.01 & 4.65 \\
\hline KH-3 & 0.85 & 4.20 & 19.20 & 4.57 \\
\hline KPM-1 & 1.05 & 4.23 & 26.70 & 6.31 \\
\hline KPM-2 & 1.10 & 4.40 & 26.50 & 6.04 \\
\hline KPM-3 & 1.00 & 4.30 & 25.90 & 6.02 \\
\hline YC-1 & 0.85 & 4.10 & 19.53 & 4.81 \\
\hline YC-2 & 0.90 & 4.04 & 19.09 & 5.16 \\
\hline
\end{tabular}




\section{CONCLUSIONS}

In restoration of historical buildings, lime mortars used as original materials in such structures should be defined by physical, mechanical and chemical analyses in macro and micro levels.

In this study, the material properties of lime mortar used in historical stone structures (14th century) in the ancient city of Becin, located in southwest Turkey and hosted many civilizations (Byzantine, Ottoman and Menteshe Emirate), were investigated and it has been shown that they have normal density, porosity and compressive strength.

Lime mortar samples of current study were examined with XRD analysis and have been shown that they consist of calcite, quartz, feldispar and small amount of clay minerals.

Microstructural properties of lime and aggregates used in mortars have been determined with Scanning Electron Microscope with EDS unit. In order to determine hydraulic characteristics of lime, chemical compositions of the lime have been calculated by using hydraulicity and cementation index. Results show that the lime used in mortars have hydraulic properties. SEM analysis reveals good bonding between binder and aggregate.

In addition, in order to determine hydraulic properties of mortars thermographic analysis (TGA/DTA) have been used. All the examined lime mortar samples are shown to be in hydraulic properties.

As a result of the study, it is determined that all mortar samples have hydraulic properties that is a result of hydraulic properties of binder lime.

The data obtained from this study would be able to shed light on protection, repairing and strengthening of the historical buildings before the restoration in the later stages. In other words, these results will be a guide to researchers in the selection of original materials intended for use in historical structures.

\section{Acknowledgments}

I thank to the ITU-Geochemistry Research Laboratory for ignition loss test, XRD, XRF analysis and Dr. Omer Bozkaya (PAU), Dr. Tamer Koralay (PAU) for petrographic analysis. Author would also like to thank Dr. Nazan Keskin for SEM/EDS analyses and to Dr. Gulbanu Koyundereli Çılgı (PAU) for TGA/DTA analyses.

\section{REFERENCES}

1. The Venice Charter. International Charter for the Conservation and Restoration of Monuments and Sites, 1964

2. Ashurst, J. Mortars, Plasters and Renders in Conservation. Ecclesiastical Architects and Surveyors Association, London, 1984: pp. 1-54.

3. Teutunico, J. M. A Laboratory Manual for Architectural Conservation. ICCROM Sintesi Grafica, Rome, 1988: pp. $120-168$.

4. Güleç, A., Ersen, A. Characterization of Ancient Mortars: Evaluation of Simple and Sophisticated Methods Journal of Architectural Conservation 1 1998: pp. 56-67. http://dx.doi.org/10.1080/13556207.1998.10785207
5. Feilden, B. Conservation of Historical Buildings. Butterworth-Heinemann, UK, 2003: pp. 182 - 345.

6. Schueremans, L., Cizer, O., Jannssens, E., Serre, G., Van Balen, K. Characterization of Repair Mortars for the Assessment of Their Compatibility in Restoration Projects Resarch and Practice, Construction and Building Material 25 2011: pp. 4338-4350. http://dx.doi.org/10.1016/j.conbuildmat.2011.01.008

7. Cigdem, T., Sedat, K. Impacts of Various Organic Additives on Carbonization of Lime Journal of the Faculty of Engineering and Architecture of Gazi University 27 (4) 2012: pp. $717-728$.

8. MacDonald, W. The Architecture of the Roman Empire. Yale Universty Press, New Haven and London, UK, 1965: pp. $151-270$.

9. Adam, J. P. Roman Buildings Materials and Techniques. Routledge, London and New York, 2005: pp. 1-360.

10. Lea, F.M. Investigations on Pozzolans Building Research (27) 1940: pp.1- 63.

11. Boynton, R.S. Chemistry and Technology of Lime and Limestone. Wiley\&Sons, New York, 1966: pp. 1-520.

12. TS 6809 Methods of Testing of Hardness by Mohs Hardness Scale, Turkish Standards Institute, Ankara, 1989.

13. Rilem Tests Defining the Structure Materials and Construction 13 1980: pp.73.

14. Borelli, E. Conservation of Architectural Heritage Historic Structures and Material /Porosity. Laboratory Handbook 2, ICCROM ARC, Rome, Italy, 1999: pp. 11-30.

15. TS 699 Methods of Testing for Natural Building Stones, Turkish Standards Institute, Ankara, 1987.

16. TS EN 1015-11/A1 Methods of Test for Mortar for Masonry - Part 11: Determination of Flexural and Compressive Strength of Hardened Mortar, Turkish Standards Institute, Ankara, 2007.

17. Brook, N. The Equivalent Core Diameter Method of Size and Shape Correction in Point-Load Testing International Journal of Rock Mechanics and Mining Science\&Geomechanics 22 (2) 1985: pp. 61-70.

18. ASTMD5731-08 Standard Test Method for Determination of the Point Load Strength Index of Rock and Application to Rock Strength Classifications, American Society for Testing and Materials Standards, U.S.A., 1994.

19. Middendorf, B., Knöfel, D. Use of Old and Modern Analytical Methods for the Determination of Ancient Mortars in Northern Germany Proceedings of the ${ }^{\text {rd }}$ Expert Meeting, Hamburg, NATO-CCMS Pilot Study on Conservation of Historic Brick Structures 1990: pp. $75-92$.

20. Donatello, S., Tyrer, M., Cheeseman, C.R. Comparison of Test Methods to Assess Pozzolanic Activity Cement and Concrete Composites 32 (2) 2010: pp. 121-127. http://dx.doi.org/10.1016/j.cemconcomp.2009.10.008

21. Tironi, A., Trezza, M.A., Scian, A.N., Irassar, E.F. Assessment of Pozzolanic Activity of Different Calcined Clays Cement and Concrete Composites 37 (1) 2013: pp. 319-327. http://dx.doi.org/10.1016/j.cemconcomp.2013.01.002

22. Yu, Q., Sawayama, K., Sugita, S., Shoya, M., Isojima, Y. The Reaction Between Rice Husk Ash and $\mathrm{Ca}(\mathrm{OH})_{2}$ Solution the Nature of its Product, Cement and Concrete Research, 29 1999: pp. 37-43. http://dx.doi.org/10.1016/S0008-8846(98)00172-0 
23. Paya, J., Borrachero, M.V., Monzo, J., Peris-Mora, E., Amahjour, F. Enhanced Conductivity Measurement Techniques for Evaluation of Flay Ash Pozzolanic Activity Cement and Concrete Research 31 2001: pp. 41-49.

24. Luxan, M.P., Madruga, F., Saavedra, J. Rapid Evaluation of Pozzolanic Activity of Natural Products by Conductivity Measurements Cement and Concrete Research 19 1989: pp. $63-68$.

25. Rilem Investigative Methods for the Characterisation of Historic Mortars Materials and Structures 38, Part 1 and Part 2, 2005: pp.761-769, 771-780.

26. Horwitz, W. Official methods of analysis of AOAC international (18th ed.). Association of Official Analytical Chemists, Gaithersburg, 2005: pp. 1-20.

27. Kozlu, H. Characterization of Historical Mortars and Features of Restoration Mortars In Kayseri District, PhD thesis, ITU Institute of Science and Technology, 2010: pp. $131-177$.

28. Benedetti, D., Valetti, S., Bontempi, E., Piccioli, C., Depero, L.E. Study of Ancient Mortars From the Roman Villa of Pollio Felice İn Sorrento (Naples) Applied Physics A 79 2004: pp. 341-345. http://dx.doi.org/10.1007/s00339-004-2529-x

29. Stefanidou, M. Methods for Porosity Measurement İn Lime-Based Mortars Construction and Building Material 24 2010: pp. 2572-2578.

30. Oguz, C., Türker, F., Koçkal, N.U. Properties of Roman, Byzantine and Seljuk Period Mortar in Andriake Harbour
Technical Journal of Turkish Chamber of civil Engineerings 26 (1) 2015: pp. 6993-7013.

31. Ulukaya, S., Yüzer, N., Yoruç, A. B. Experimental Method Applied to the Identification of Lime Mortar, Byzantine, Seljuk and Ottoman Structure Sample of Investigation (in Turkish) $4^{\text {nd }}$ Strengthening of Historical Buildings and safely transferred to the Future Symposium 289-300 2013.

32. Ugurlu-Sagın, E., Böke, H. Characteristics of Roman Mortar (Cocciopesto) (in Turkish) $4^{\text {nd }}$ Strengthening of Historical Buildings and Safely Transferred to the Future Symposium 131-140 2013.

33. Boyton, R.S. Chemistry and Tecnology of Lime and Limestone $2^{\text {nd }}$ edition, Jhon Wiley\&Sons, New York, USA, 1980.

34. Vicat, L.J. Mortars and Cements. Donhead Publis Ltd, Dorset, UK, 2003: pp. 180-352.

35. Muğla Province Mining and Energy Resources, 2010, http://www.mta.gov.tr (April, 2014).

36. Bruni, S., Cariati, F., Fermo, P., Cairati, P., Alessandrini, G., Toniolo, L. White Lumps in Fifth - to Seventeenth-Century AD Mortars from Northern Italy Archaeometry 39/1 1997: pp. 1-7.

37. Cizer, Ö., Böke, H., İpekoğlu, B. The Characteristics of Lime Mortar Used in Domes and Walls of some Structures From Ottoman Era (in Turkish) 2nd National congress and Exhibition of Structural Material 2004: pp. 469-481. 